\title{
The Role of Receptor Activator of NF-kB Ligand in Smooth Muscle Cell Proliferation
}

\author{
Hyun-Ju Kim* \\ Division of Molecular and Life Sciences, Pohang University of Science and Technology, Pohang, 790-783, Kyungbuk, South Korea
}

Received September 27, 2006 / Accepted October 12, 2006

\begin{abstract}
Smooth muscle cell (SMC) proliferation is important in the pathogenesis of vascular proliferative disorders. Understanding of the molecular mechanism underlying SMC growth after arterial injury would have therapeutic implications. Here we report that receptor activator of $\mathrm{NF}-\mathrm{KB}$ ligand (RANKL), a member of tumor necrosis factor (TNF) family, promotes the proliferation of SMC, leading to decreased expression of p21 and enhancement of SMC growth. ERK and p38 phosphorylation was enhanced after RANKL treatment in SMC. Inhibition of ERK/p38 MAPK activity by PD98059/ SB203580 completely abolished RANKL-induced proliferation of SMC, indicating ERK and p38 MAPK are essential for RANKL-induced SMC proliferation. Taken together, our findings demonstrate that RANK-RANKL-ERK/p38 pathway is important for proliferation of SMC and that these molecules may be the new therapeutic targets for the prevention of vascular diseases.
\end{abstract}

Key words - RANKL, SMC, proliferation, ERK, p38

\section{Introduction}

Smooth muscle cell (SMC) proliferation and migration after arterial injury plays an important role in the pathogenesis of a number of vascular proliferative disorders, including atherosclerosis and restenosis after balloon angioplasty and hypertension[16]. The neointima formation that is characterized by the enhanced proliferation and migration of SMCs is triggered by a complex interaction of various growth-regulatory molecules[9]. These molecules include growth factors such as platelet-derived growth factor (PDGF) and basic fibroblast growth factor (bFGF), and insulin like growth factor I (IGF-I)[15] and cytokines such as transforming growth factor $\beta$ (TGF- $\beta$ ) and interleukin-1 (IL-1)[14,17]. On the other hands, interferon- $\gamma$ (IFN- $\gamma$ ) and progesterone are known to inhibit SMC growth[8,18].

The tumor necrosis factor (TNF) family molecule, receptor activator of NF- $\mathrm{KB}$ ligand (RANKL; also called OPGL, ODF, and TRANCE) is a cytokine that regulates osteoclast differentiation and activation of dendritic cells $[6,20]$. Mice lacking RANKL reveal a complete absence of osteoclast following severe osteopetrosis and failure in tooth eruption. RANKL also regulates the interaction of $\mathrm{T}$ cell and dendritic cells, thereby promoting dendritic cell survivial [19]. In addition, RANKL plays an essential role in mammary gland development during pregnancy[2].

* Corresponding author

Tel : +82-54-770-8209, Fax : +82-54-770-8378

E-mail : hkim@path.wustl.edu
RANKL deficient mice exhibit impaired lobulo-alveolar development during pregnancy owing to intrinsic defects in both proliferation and survival of mammary gland epithelial cells[2].

We report here that RANKL stimulation of smooth muscle cells induces SMC proliferation. RANKL up-regulates ERK and p38 MAPK phosphorylation in primary human smooth muscle cells. Inhibiors of ERK/p38 completely blocked RANKL-derived SMC proliferation. These results identify RANKL as a novel regulator for the proliferation of smooth muscle cells via ERK/p38 MAPK pathway.

\section{Materials and Methods}

\section{Cell culture}

Pimary human aortic smooth muscle cells (HASMC) were maintained in Dulbecco's modified Eagle's medium (DMEM) supplemented with $10 \%$ fetal bovine serum. Cells were used between passages 8 and 10 .

\section{FACS analysis}

The human smooth muscle cells were stained with RANKL-fluorescein isothiocyanate (FITC) and analyzed by flow cytometer to detect RANK expression.

\section{Immunoblotting}

Whole cell extracts were obtained as follows. Cells were lysed in extraction buffer $[10 \mathrm{mM}$ Tris ( $\mathrm{pH} 7.5$ ), $150 \mathrm{mM}$ $\mathrm{NaCl}, 5 \mathrm{mM}$ EDTA, $1 \mathrm{mM} \mathrm{Na} \mathrm{VO}_{4}, 1 \%$ Triton $\mathrm{X}-100$, and 
Complete Protease Inhilitor Mixture tablet], incubated at $4^{\circ} \mathrm{C}$ for $10 \mathrm{~min}$ by shaking and then cleared by centrifugation. Protein concentrations were determined using a bicinchoninic acid assay. Equal amounts of whole cell extracts were separated on SDS-PAGE and transferred to PVDF membranes. Membranes were incubated with antibodies to p21, ERK1 (Santa Cruz Biotechnology), and phospho-p38 (Cell Si gnaling Technology). Protein bands were detected by enhanced chemiluminescence (Amersham Pharmacia Biotech).

\section{Proliferation Assay}

Cell proliferation was assessed by $\left[{ }^{3} \mathrm{H}\right]$-thymidine incorporation. Cells were plated at low density, allowed to attach overnight in DMEM supplemented with 10\% FBS, and then serum-starved with DMEM containing $0.5 \%$ FBS and $0.2 \%$ BSA for $24 \mathrm{hr}$ prior to RANKL stimulation. $[\mathrm{H} H$-thymine were added $12 \mathrm{hr}$ before harvest and cells vere collected 24 or $72 \mathrm{hr}$ after RANKL stimulation. For irhibitor treatment experiment, SMCs were incubated with or without ERK inhibitor PD98059 $(30 \mu \mathrm{M})$ or p38 inhibitor

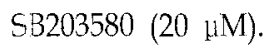

\section{Promoter reporter Assays}

SMCs were transiently transfected using lipofectamine plus reagent (Life Technologies) with 500 or $1000 \mathrm{ng}$ of plasmid DNA (p21-Luc) per 12 well plates. The Renilla reporter construct pRL-TK (Promega) was used for normalizing transfection efficiency. After transfection, cells were incubated for $24 \mathrm{hr}$ in DMEM containing 0.5\% FBS and 0.2\% BSA and harvested after $24 \mathrm{hr}$ of stimulation with RANKL. Luciferase activity was determined using the DualLuciferase Repoter Assay System (Promega).

\section{Results}

\section{RANKL induces proliferation of SMC}

Proliferation of smooth muscle cells is regulated by a number of growth factors and cytokines in the formation of atherosclerotic lesions. RANKL is a cytokine which belongs to TNF family members. To address whether RANKL is capable of inducing the proliferation of smooth muscle cells, we used primary human aortic smooth muscle cells (HASMC). Prior to evaluating direct effects of RANKL on SMC growth, we examined the presence of RANK, the receptor of RANKL, in the cultures of HASMC by FACS analysis. As shown in Fig. 1, we observed RANK

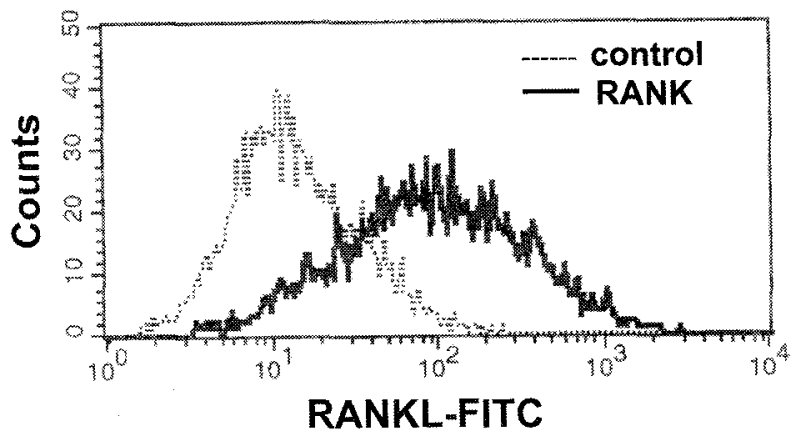

Fig. 1. Expression of RANK, the receptor of RANKL in smooth muscle cells (SMCs). FACS analysis of primary human SMCs with RANKL-FITC shows RANK expression (solid line). The dotted lines represent the background fluorescence of unstained cells.

expression on the surface of human SMC. We next investigated the effects of RANKL on the proliferation of SMC by $\left[{ }^{3} \mathrm{H}\right]$-thymidine incorporation into DNA. Treatment of SMC with RANKL for 24 hr (Fig. 2A) or 72 hr (Fig. 2B) resulted in a significant dose-dependent increase in DNA

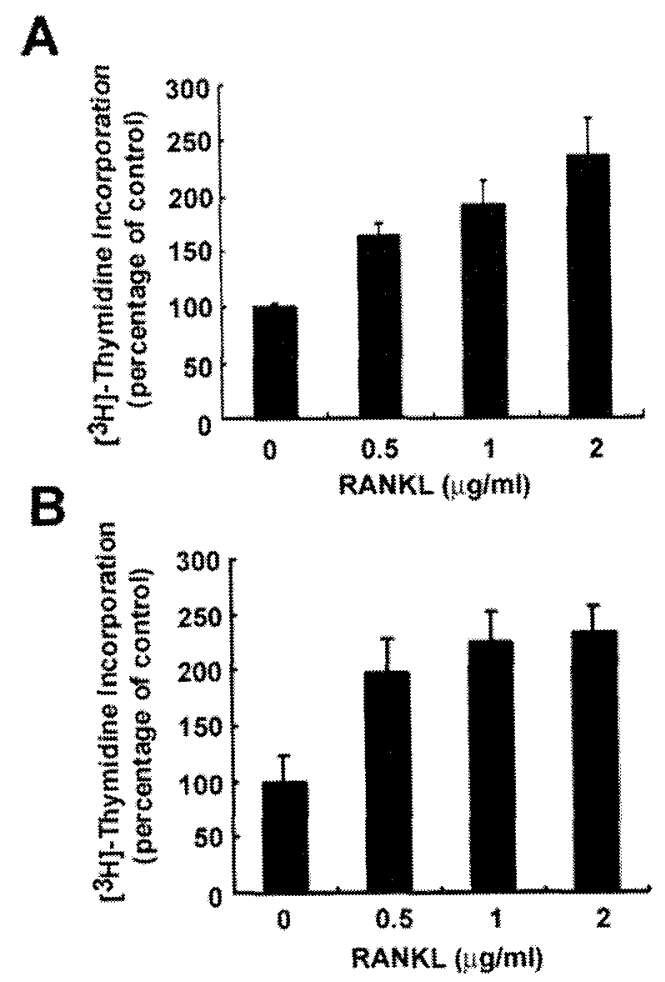

Fig. 2. RANKL induces SMC growth. Serum-starved SMCs were stimulated with the indicated doses of RANKL for $24 \mathrm{hr}$ (A) or $72 \mathrm{hr}$ (B). Cells were incubated with $1 \mathrm{mCi} / \mathrm{ml}$ of $\left[{ }^{3} \mathrm{H}\right]$-thymidine for the last $12 \mathrm{hr}$ of culture and $\left[{ }^{3} \mathrm{H}\right]$-thymidine incorporation was measured. Results are shown as mean values \pm S.E.M. of three separate experiments. 
synthesis of HASMC in DMEM containing 0.5\% FBS. These data demonstrate that RANKL directly induces the proliferation of smooth muscle cells.

ERK and p38 MAPK are central to RANKLinduced SMC proliferation

It has been known that mitogen-activated protein kinases (MAPK) such as extracellular-signal regulated kinase (ERK) and p38 MAP kinase are associated in the cascade leading to the proliferation of SMC[3]. To test whether ERK or p38 signaling pathway mediates RANKL-induced SMC proliferation, we first examined the effects of RANKL on the phosphorylation of ERK or p38. As shown in Fig. 3, RANKL readily activated/phosphorylated both ERK (Fig. 3A) and p38 (Fig. 3B) after 5 min treatment in SMC, similar to osteoclast and dendritic cells. We next examined the effects of inhibitors on RANKL-induced SMC proliferation. Cells were treated with or without the inhibitors of either ERK (PD98059) or p38 MAP kinase inhibitor (SB203580). Treatment of SMC with either PD98059 or SB203580 completely abolished RANKL-induced proliferation of SMC (Fig. 4). These results indicate that ERK and p38 MAPK pathways play an important role in RANKL-induced SMC proliferation.

A

\section{RANKL}

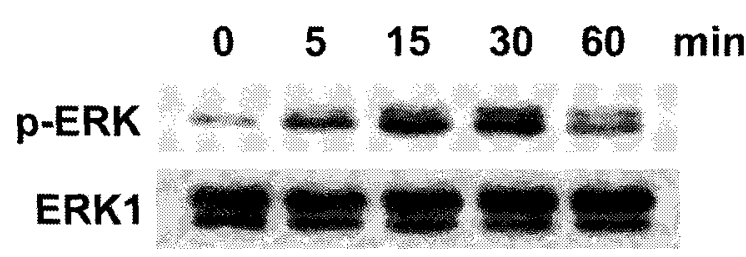

B

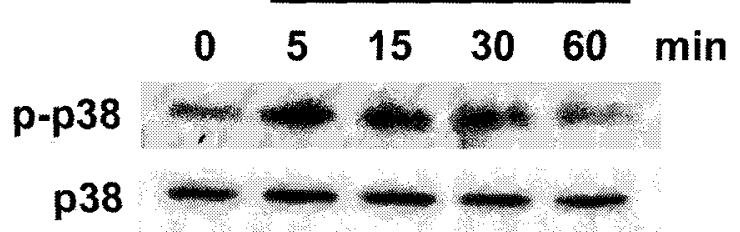

Fig. 3. RANKL enhances ERK and p38 MAKP activity. Activation of ERK and p38 MAPK after RANKL treatment. SMCs were treated with $1 \mathrm{mg} / \mathrm{ml}$ RANKL for the indicated time periods. Phosphorylated forms of ERK (A), and p38 (B) in whole-cell extracts were detected with phospho-specific Abs. The membranes were stripped and probed with Ab against ERK or p38 as indicated.

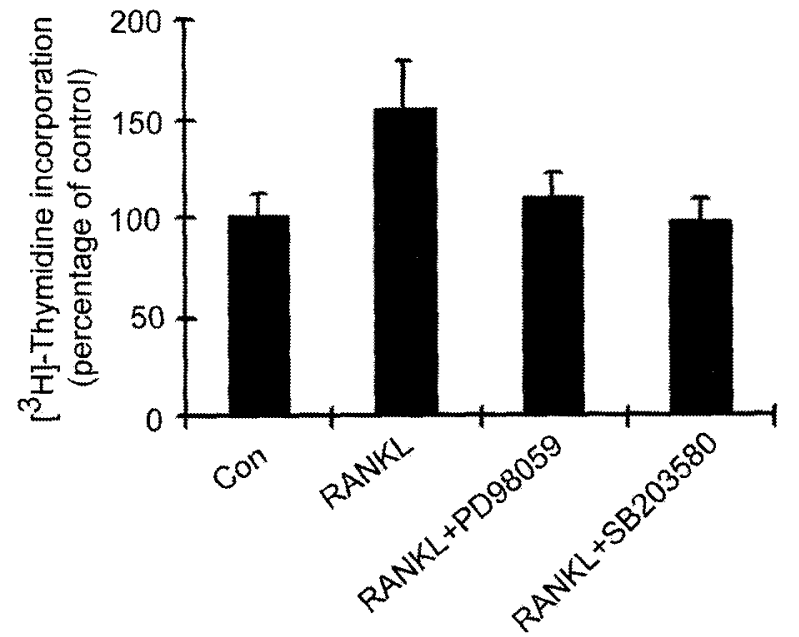

Fig. 4. ERK and p38 is important for RANKL-induced SMC proliferation. SMCs were incubated with or without either ERK inhibitor PD98059 $(30 \mu \mathrm{M})$ or p38 inhibitor SB203580 $(20 \mu \mathrm{M})$. Cells were stimulated with 1 $\mathrm{mg} / \mathrm{ml}$ RANKL for $24 \mathrm{hr}$. Then cells were incubated with $1 \mathrm{mCi} / \mathrm{ml}$ of $\left[{ }^{3} \mathrm{H}\right]$-thymidine for the last $12 \mathrm{hr}$ of culture and $\left[{ }^{3} \mathrm{H}\right]$-thymidine incorporation was measured. Results are shown as mean values \pm S.E.M. of three separate experiments.

\section{Downregulation of p21 expression by RANKL}

Since previous studies have revealed that cyclin-dependent kinase inhibitors play an essential role in cell cycle regulation in SMC[10-12], we assessed the levels of p21 expression following RANKL stimulation in smooth muscle cells. As shown in Fig. 5A, p21 expression was decreased after RANKL treatment for $24 \mathrm{hr}$ in SMC compared to control treatment. To further confirm the effects of RANKL on the expression of p21, SMCs were transiently transfected with a luciferase construct containing the p21 promoter (p21-Luc). RANKL stimulation of SMCs transfected with 500 or $1000 \mathrm{ng}$ DNA of p21-Luc resulted in 29 or $52 \%$ decrease of p21 promoter activity, respectively (Fig. 5B). Thus, RANKL-RANK activation regulates the expression levels of the cell cycle inhibitor p21-WAF1 in smooth muscle cells.

\section{Discussion}

Receptor activator of NF-xB ligand plays a key role for osteoclast development/activation and skeletal calcium release. In addition, RANKL is a critical factor in mammary gland development[2]. In the present study, we show smooth muscle cells express RANK, the receptor of 
A

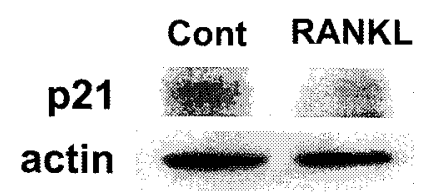

B

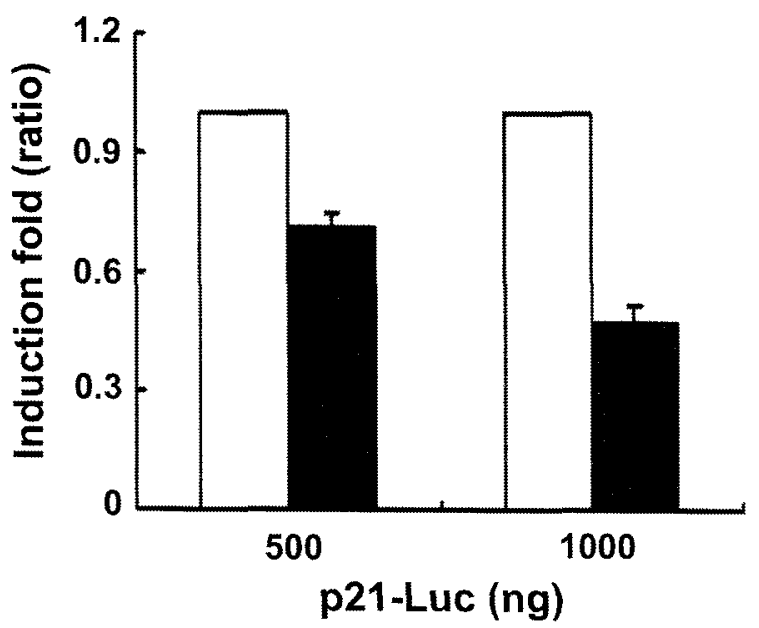

Fig. 5. RANKL inhibits p21 expression in smooth muscle cells (A) Western blot analysis of p21 expression in SMC. SMCs were left untreated (cont) or treated with $1 \mu \mathrm{g} / \mathrm{ml}$ RANKL for 24 hr. Actin is shown as a protein loading control. (B) p21-promoter luciferase assays in SMCs. Transfected SMCs with p21-Luc were left untreated $(\square)$ or treated with (प) $1 \mathrm{~kg} / \mathrm{ml}$ RANKL for $24 \mathrm{hr}$. Luciferase reporter activity was normalized to Renilla luciferase activity. Results are shown as mean values \pm S.E.M. of three separate transfection experiments.

RANKL, and RANKL induces the proliferation of SMC, suggesting for the first time an essential role for RANKL in the proliferation of SMC.

Mitogen-activated protein kinases (MAPK) such as ERK, INK, and p38 MAPK have been implicated in the signaling cascades involved in the proliferation and hypertrophy of SMC [3]. They are commonly activated by vascular remodeling-related molecules and play the central role in the initiation of cellular responses, including cellular gene expression, growth, migration, or apoptosis[1]. Treatment with growth factors such as PDGF and bFGF, which induce the proliferation and migration of SMC, activates ERK and p38[4], ERK[13], ERK/JNK [5] or p38[7] are enhanced in rat carotid arteries after balloon injury. These findings suggest that smooth muscle disorders are closely associated with the activation of MAPKs. In our study, both ERK and p38 were rapidly activated in cultured SMC in response to RANKL and treatment of their specific in- hibitors blocked RANKL-induced SMC proliferation, indicating that RANKL-mediated ERK and p38 activation play a role in the signaling pathway implicated in the proliferation of SMC.

A molecular mechanism of RANKL-mediated proliferation of SMC is through the regulation of the cdk inhibitor p21-WAF1. During early to mid G1 of the cell cycle, Id proteins antagonize the helix-loop-helix transcription factor E2A that regulate the expression of p21, leading to the enhanced cell growth[10]. In our present study, the expression of p21 was downregulated following RANKL/RANK stimulation in SMC, indicating that RANKL-induced downmodulation of p21

Several growth factors including PDGF, bFGF, IGF-I, and proinfalmmatory cytokines including TGF- $\beta$ and IL-1 are known to regulate proliferation and migration of vascular SMCs $[15,17]$. In the present study, we demonstrate that RANKL is a novel molecule that promotes SMC proliferation and $\mathrm{p} 21$ regulation. Our findings provide a new signaling pathway that controls proliferation of smooth muscle cells. Since the proliferation of SMC is critical in the onset of serious diseases such as atherosclerosis and hypertension, understanding of the factors that regulates RANKL expression may provide potential therapeutic targets for preventing vascular proliferative disorders.

\section{References}

1. Cano, E. and L. C. Mahadevan 1995. Parallel signal processing among mammalian MAPKs. Trends Biochem. Sci. 20, 117-122.

2. Fata, J. E., Y. Y. Kong, J. Li, T. Sasaki, J. Irie-Sasaki, R. A. Moorehead, R. Elliott, S. Scully, E. B. Voura, D. L. Lacey, W. J. Boyle, R. Khokha and J. M. Penninger. 2000. The osteoclast differentiation factor osteoprotegerin-ligand is essential for mammary gland development. Cell 103, 41-50.

3. Force, T. and J. V. Bonventre 1998. Growth factors and mitogen-activated protein kinases. Hypertension 31, 152-161.

4. Hayashi, K., M. Takahashi, K. Kimura, W. Nishida, H. Saga and K. Sobue.1999. Changes in the balance of phosphoinositide 3-kinase/protein kinase B (Akt) and the mitogen-activated protein kinases (ERK/p38MAPK) determine a phenotype of visceral and vascular smooth muscle cells. I. Cell Biol. 145, 727-740.

5. Izumi, Y., S. Kim, M. Namba, H. Yasumoto, H. Miyazaki, M. Hoshiga, Y. Kaneda, R. Morishita, Y. Zhan and H. Iwao. 2001. Gene transfer of dominant-negative mutants of extracellular signal-regulated kinase and c-Jun NH2-terminal kinase prevents neointimal formation in balloon-injured rat artery. Cir. Res. 88, 1120-1126. 
6. Lacey, D. L., E. Timms, H. L. Tan, M. J. Kelley, C. R. Dunstan, T. Burgess, R. Elliott, A. Colombero, G. Elliott, S. Scully, H. Hsu, J. Sullivan, N. Hawkins, E. Davy, C. Capparelli, A. Eli, Y. X. Qian, S. Kaufman, I. Sarosi, V. Shalhoub, G. Senaldi, J. Guo, J. Delaney and W. J. Boyle.1998. Osteoprotegerin ligand is a cytokine that regulates osteoclast differentiation and activation. Cell 93, 165-176.

7. Larrivee, J. F., D. R. Bachvarov, F. Houle, J. Landry, J. Huot and F. Marceau. 1998. Role of the mitogen-activated protein kinases in the expression of the kinin B1 receptors induced by tissue injury. I. Immunol. 160, 1419-1426.

8. Lee, W. S., J. A. Harder, M, Yoshizumi, M.E. Lee and E. Haber.1997. Progesterone inhibits arterial smooth muscle cell proliferation. Nat. Med. 3, 1005-1008.

9. Libby, P., D. Schwartz, E. Brogi, H. Tanaka and S. K. Clinton. 1992. A cascade model for restenosis. A special case of atherosclerosis progression. Circulation 86, 1114711152.

10. Matsumura, M. E., D. R. Lobe and C. A. McNamara. 2002. Contribution of the helix-loop-helix factor Id2 to regulation of vascular smooth muscle cell proliferation. J. Biol. Chem. 277, 7293-7297.

11. Mueller, C., S. Baudler, H. Welzel, M. Bohm and G. Nickenig. 2002. Identification of a novel redox-sensitive gene, Id3, which mediates angiotensin II-induced cell growth. Circulation 105, 2423-2428.

12. Prabhu, S., A. Ignatova, S. T. Park and X. H. Sun.1997. Regulation of the expression of cyclin-dependent kinase inhibitor p21 by E2A and Id proteins. Mol. Cell Biol. 17, 5888-5896.

13. Pyles, J. M., K. L. March, M. Franklin, K. Mehdi, R. L.
Wilensky and L. P.Adam. 1997. Activation of MAP kinase in vivo follows balloon overstretch injury of porcine coronary and carotid arteries. Cir. Res. 81, 904-910.

14. Raines, E. W., S. K. Dower and R. Ross. 1989. Interleukin-1 mitogenic activity for fibroblasts and smooth muscle cells is due to PDGF-AA. Science 243, 393-396.

15. Reidy, M. A., J. Fingerle and V. Linder,. 1992. Factors controlling the development of arterial lesions after injury. Circulation 86, 11143-11146.

16. Schwartz, S. M. 1999. The intima : A new soil. Cir Res. 82(10), 877-879.

17. Stouffer, G. A. and G. K. Owens. 1994. TGF-beta promotes proliferation of cultured SMC via both PDGF-AA-dependent and PDGF-AA-independent mechanisms. J. Clin. Invest. 86, 2048-2055.

18. Warner, S. J., G. B. Friedman and P. Libby. 1989. Immune interferon inhibits proliferation and induces $2{ }^{\prime}-5$-oligoadenylate synthetase gene expression in human vascular smooth muscle cells. J. Clin. Invest. 83, 1174-1182.

19. Wong, B. R., R. Josien, S. Y. Lee, B. Sauter, H. L. Li, R. M. Steinman and Y. Choi. 1997. TRANCE (tumor necrosis factor [TNF]-related activation-induced cytokine), a new TNF family member predominantly expressed in $\mathrm{T}$ cells, is a dendritic cell-specific survival factor. J. Exp. Med. 186, 2075-2080.

20. Wong, B. R., J. Rho, J. Arron, E. Robinson, J. Orlinick, M. Chao, S. Kalachikov, E. Cayani, F. S. Bartlett, W. N. Frankel, S. Y. Lee and Y. Choi. 1997. TRANCE is a novel ligand of the tumor necrosis factor receptor family that activates c-Jun $\mathrm{N}$-terminal kinase in T cells. J. Bio. Chem. 272, 25190-25194.

\title{
초록 : Smooth muscle cell 증식에 있어 NF-kB ligand의 receptor activator의 역할
}

\author{
김 현 주* \\ (포항공과대학교 생명과학부)
}

Smooth muscle cell $(\mathrm{SMC})$ 의 증식은 혈관성장에 의한 질환의 발병기전의 중요한 요소이다. 혈관 손상 후 $\mathrm{SMC}$ 의 성장조절에 대한 분자적 기작에 대한 연구는 치료제 개발에 있어 중요한 의미를 지넌다. 이에, 본 연구에서는 TNF family인 RANKL가 SMC의 증식을 촉진함을 입증하였다. RANKL는 p21의 발현을 감소시키고 p21의 promoter활성을 저해함으로써 SMC의 성장을 증가시켰다. 또한 ERK와 p38 MAPK의 활성이 RANKL에 의해 증가 하였으며, $\mathrm{ERK} / \mathrm{p} 38$ 의 저해제는 RANKL에 의해 유도되는 SMC의 성장을 완전히 억제하였다. 이러한 결과는 ERK와 p38 MAPK가 RANKL에 의해 유도되는 $\mathrm{SMC}$ 의 증식에 중요한 역할을 함을 보여주는 것이다. 즉, RANK-RANKL-ERK/p38이 SMC의 증식을 매개하는 중요 분자이며, 이들 분자는 혈관 질환을 막는 새로운 치료 제 개발의 표적분자가 될 수 있음이 입중되었다. 